\title{
SPLETNA ORODJA ZA SLOVENŠČINO IN TUJI ŠTUDENTI UNIVERZE V LJUBLJANI
}

\author{
Mojca STRITAR KUČUK
}

Filozofska fakulteta, Univerza v Ljubljani

Stritar Kučuk, M.: Spletna orodja za slovenščino in tuji študenti Univerze v Ljubljani. Slovenščina 2.o, 9(2): 100-125.

DOI: https://doi.org/10.4312/slo2.0.2021.2.100-125

Redno vpisani tuji študenti Univerze v Ljubljani, ki se v prvem letu študija v okviru modula Leto plus učijo slovensko, se v drugem semestru na posebni delavnici podrobneje spoznajo s spletnimi jezikovnimi viri in tehnologijami za slovenščino. V prispevku je opisana izvedba te delavnice v študijskem letu 2019/20, ko je zaradi pandemije koronavirusa potekala na daljavo, v obliki interaktivnih videoposnetkov z nalogami za preverjanje razumevanja snovi. Drugi del prispevka se osredotoča na mnenje študentov o tovrstnih jezikovnih virih. S spletno anketo sem analizirala stališča in izkušnje študentov dveh generacij: študenti generacije 2018/19 so spletna orodja spoznavali v razredu, študenti generacije 2019/20 pa na daljavo. Sodeč po rezultatih ankete, mlajša generacija študentov jezikovne vire na spletu uporablja pogosteje. Študenti obeh skupin najpogosteje uporabljajo Googlov Prevajalnik, ki mu sledijo Sloleks, pregibnik Besana, Fran in Pons. Kot argumente za uporabo teh virov izpostavljajo predvsem hitrost oz. enostavnost uporabe in navajenost na določen vir.

Ključne besede: spletni jezikovni viri, slovenščina, tuji študenti, spletno učenje

\section{UVOD}

Spletni jezikovni viri in jezikovne tehnologije si pot med uporabnike utirajo zlagoma in ob precejšnjem trudu jezikoslovcev. ${ }^{1}$ Precej je bilo storjenega za ozaveščanje učiteljskega osebja v slovenskih šolah (prim. Arhar Holdt idr., 2021; Stritar Kučuk, Dobrovoljc, 2013; Portal jezikovnih virov), še večji izziv

1 Moška oblika je v tem prispevku uporabljena kot slovnično nevtralna. 
pa jih je širiti med populacijo, ki ni več vključena v redni jezikovni pouk. V tem prispevku predstavljam, kako se s spletnimi jezikovnimi viri za slovenščino sistematično seznanja specifična skupina govorcev slovenščine, namreč tuji študenti na Univerzi v Ljubljani. Redno vpisani tuji študenti so v prvem letu študija upravičeni do udeležbe v modulu Leto plus, namenjenem usposabljanju za študij v Sloveniji. Med drugim vključuje dva semestra brezplačnega lektorata slovenščine kot drugega jezika. Vsako leto se v Leto plus vpiše med 300 in 350 študentov. Večina jih prihaja iz južnoslovanskega govornega področja (Grafikon 1) in se slovenščine pred prihodom na študij v Ljubljani ne uči.

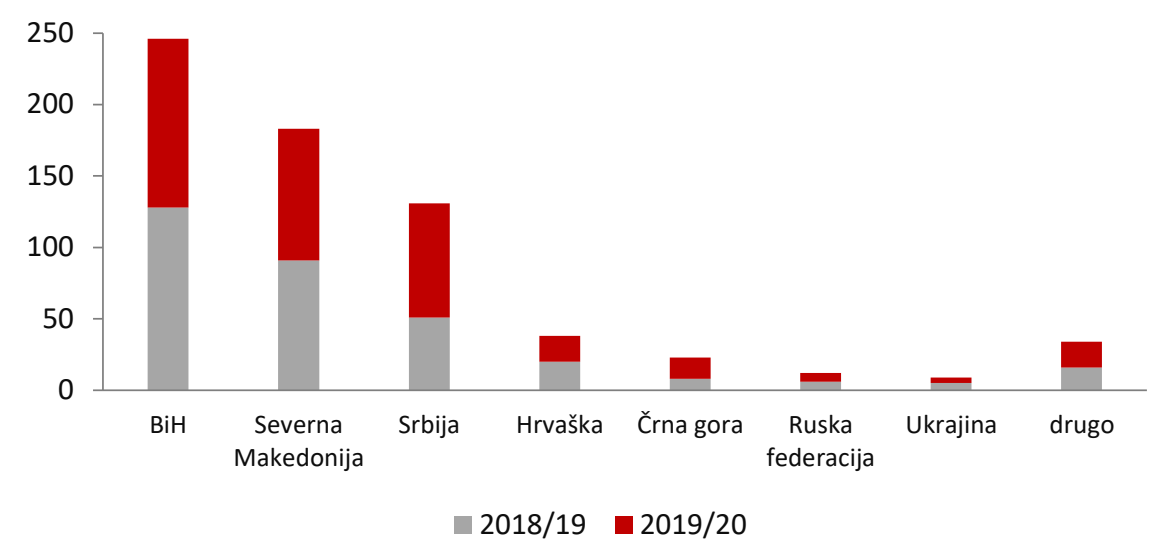

Grafikon 1: Študenti Leta plus po državi izvora.

Vsak semester lektorata slovenščine pomeni 60 ur pouka slovenščine kot drugega jezika, in sicer 45 kontaktnih ur z učiteljem v razredu, poleg tega pa še 15 ur dodatnega programa, med katerega sodijo dejavnosti z učiteljem, kot so fonetične vaje ali konverzacija, pa tudi udeležba na različnih kulturnih dogodkih in podobno. V drugem semestru, ko so študenti že bolj suvereni pri samostojnem pisanju v slovenščini, je eden od dodatnih projektov delavnica uporabe spletnih jezikovnih virov in tehnologij za slovenščino.

To za večino študentov sicer ni prvo srečanje z uporabo jezikovnih virov in tehnologij. Večina je navajena, da si pri slovenščini pomaga z Googlovim Prevajalnikom, ki pa ga po izkušnjah lektorjev slovenščine pogosto uporabljajo nekritično. Zato jih od uvodnih ur lektorata naprej skušamo opozarjati na pomembnost kritične uporabe in jih hkrati seznanjamo tudi z drugimi 
jezikovnimi viri. Ko je to pedagoško smiselno, jim npr. pokažemo slovarski portal Fran, korpus Gigafida 2.0 ipd. V večje podrobnosti pri uporabi pa se usmerimo prav na posebej temu namenjeni delavnici. Namen tega prispevka je torej predstaviti omenjeno delavnico in prek analize rabe posameznih jezikovnih virov in tehnologij, ki temelji na samoevalvaciji študentov, oceniti njeno uspešnost.

\section{SPLETNA DELAVNICA UPORABE JEZIKOVNIH VIROV}

Delavnica uporabe jezikovnih virov je v prvih letih modula Leta plus, ki je bil prvič izveden v študijskem letu 2017/18, potekala fizično. V študijskem letu 2018/19 so si denimo študenti izbrali enega od desetih terminov, v katerem so v računalniški učilnici v skupinah po 30 opravili triurno usposabljanje. ${ }^{2} \mathrm{~V}$ študijskem letu 2019/20 pa smo bili delavnico zaradi pandemije covida 19 in prekinitve študijskega procesa na univerzi prisiljeni v celoti prestaviti na splet. Poimenovana je bila Spletna orodja za slovenščino (kratko SOS za slovenščino). Delavnica je bila izpeljana kot komplet interaktivnih videoposnetkov v spletni učilnici Filozofske fakultete. ${ }^{3}$ Vsak posnetek je predstavil enega ali več sorodnih jezikovnih virov. Ker je bila delavnica namenjena vsem študentom, ne samo jezikoslovcem, so bile informacije podane splošno, brez zgodovinskih pregledov, bolj specifičnih informacij ali naprednih možnosti iskanja. Skupaj je bilo posnetih sedem videoposnetkov oz. okoli 40 minut gradiva. Študenti so si morali ogledati vse videoposnetke in rešiti z njimi povezane naloge, kar je bil eden od pogojev za pristop k izpitu.

\subsection{Predstavljeni jezikovni viri in tehnologije}

Ker je jezikovnih virov za slovenščino vedno več in se hitro razvijajo, je bilo treba izbrati tiste, ki jih je smiselno predstaviti po interesih in jezikovnem predznanju precej raznorodni skupini tujih študentov. Odločitev je bila sprejeta predvsem na podlagi naših predvidevanj o tem, kateri viri in tehnologije ponujajo podatke, ki so za te študente najbolj relevantni in uporabni (Tabela 1). Izbrani so bili viri, ki so prosto dostopni in predstavljajo predvsem sodobno standardno oz. knjižno slovenščino, pa tudi nekaj terminoloških oz. bolj

2 Delavnico je pripravila in izvajala dr. Tadeja Rozman.

3 Delavnico sem na osnovi gradiva prejšnjih let pripravila avtorica tega prispevka. 
strokovnih virov. Pomemben dejavnik je bila tudi enostavnost uporabe samega vira.

Tabela 1: Jezikovni viri in tehnologije, vključeni $v$ delavnico spletnih orodij za slovenščino

\begin{tabular}{|c|c|c|c|}
\hline Tip izdelka & $\begin{array}{l}\text { Jezikovni vir } \\
\text { oz. tehnologija }\end{array}$ & Opis & Spletna povezava \\
\hline \multirow{6}{*}{$\begin{array}{l}\text { Slovarji in } \\
\text { slovarski } \\
\text { portali }\end{array}$} & Pons & Večjezični spletni slovar & https://sl.pons.com/ \\
\hline & $\begin{array}{l}\text { Slovarji: Spletni } \\
\text { slovarji in } \\
\text { prevajalski } \\
\text { pripomočki }\end{array}$ & $\begin{array}{l}\text { Spletna stran s } \\
\text { povezavami na različne } \\
\text { slovarje in prevajalske } \\
\text { pripomočke }\end{array}$ & $\begin{array}{l}\text { https://evroterm.vlada.si/ } \\
\text { slovarji }\end{array}$ \\
\hline & Termania & $\begin{array}{l}\text { Spletni slovarski portal s } \\
\text { slovarji podjetja Amebis }\end{array}$ & https://www.termania.net \\
\hline & Fran $^{4}$ & $\begin{array}{l}\text { Spletni slovarski portal } \\
\text { s slovarji Inštituta za } \\
\text { slovenski jezik Frana } \\
\text { Ramovša ZRC SAZU }\end{array}$ & https://fran.si/ \\
\hline & Kolokacije 1.0 & $\begin{array}{l}\text { Slovar kolokacij sodobne } \\
\text { slovenščine (prim. } \\
\text { Kosem idr., 2018) }\end{array}$ & https://viri.cjvt.si/kolokacije/ \\
\hline & Sopomenke 1.0 & $\begin{array}{l}\text { Slovar sopomenk } \\
\text { sodobne slovenščine } \\
\text { (prim. Krek idr., 2018; } \\
\text { Arhar Holdt idr., 2018) }\end{array}$ & $\begin{array}{l}\text { https://viri.cjvt.si/ } \\
\text { sopomenke/ }\end{array}$ \\
\hline $\begin{array}{l}\text { Jezikovni } \\
\text { korpusi }\end{array}$ & Gigafida 2.0 & $\begin{array}{l}\text { Korpus pisne standardne } \\
\text { slovenščine (prim. Krek } \\
\text { idr., 2020) }\end{array}$ & https://viri.cjvt.si/gigafida/ \\
\hline \multirow[t]{2}{*}{ Pregibanje } & Besana & Spletni pregibnik & $\begin{array}{l}\text { https://besana.amebis.si/ } \\
\text { pregibanje/ }\end{array}$ \\
\hline & Sloleks & $\begin{array}{l}\text { Slovenski oblikoslovni } \\
\text { leksikon (prim. } \\
\text { Dobrovoljc idr., 2015) }\end{array}$ & https://viri.cjvt.si/sloleks/ \\
\hline \multirow[t]{2}{*}{$\begin{array}{l}\text { Ostali } \\
\text { izdelki }\end{array}$} & $\begin{array}{l}\text { Googlov } \\
\text { Prevajalnik }\end{array}$ & Strojni prevajalnik & https://translate.google.com/ \\
\hline & $\begin{array}{l}\text { črkovalniki } \\
\text { (Microsoft, } \\
\text { Google) }\end{array}$ & $\begin{array}{l}\text { Strojni črkovalniki v } \\
\text { urejevalnikih besedil ipd. }\end{array}$ & \\
\hline
\end{tabular}

Nekaj virov, ki so bili med fizično izvedbo delavnice še del predstavitve, je bilo leto kasneje v spletni delavnici samo omenjenih: govorni korpus GOS (prim. Verdonik, Zwitter Vitez 2011), korpus Kres (prim. Logar Berginc idr., 2012), korpus učečih se Šolar (prim. Kosem idr., 2012), vzporedni korpus Evrokorpus

4 V času priprave in izvedbe delavnice otroški slovarski portal Franček še ni bil dostopen. 
(prim. Željko, 2003), aplikacija Igra besed (prim. Arhar Holdt idr., 2020). Predvidevati je namreč mogoče, da ti viri za večino naše študentske populacije niso zanimivi, so prezahtevni za njihovo jezikovno zmožnost v slovenščini ali pa so bili v času izvedbe delavnice uporabniški vmesniki premalo intuitivni za uporabo. Tisti študenti, za katere bi bili lahko koristni, pa so dovolj računalniško in jezikoslovno usposobljeni, da se lahko vanje samostojno poglobijo.

Nekaj virov, ki so bili v fizični delavnici predstavljeni, pa v spletno delavnico sploh ni bilo vključenih. Taka sta Pedagoški slovnični portal, ki je bolj kot tujcem namenjen domačim govorcem slovenščine in njihovim težavam (prim. Kosem idr. 2012, 108-122), in poskusni Spletni slovar slovenskega jezika kot testni prikaz gesel leksikalne baze za slovenščino (prim. Gantar, 2011), ki za tuje govorce vsebuje premalo gesel.

\subsection{Predstavitev jezikovnega vira}

Osnova vsakega videoposnetka je predstavitev določenega vira oz. tehnologije, ki je kratka, pripravljena v jeziku, za katerega predvidevamo, da je razumljiv tujim študentom, in osredotočena na informacije, ki so zanje pomembne. To sta predvsem podatka, kaj najdejo v viru in zakaj je to koristno. V videoposnetkih so izpostavljene tudi omejitve oz. slabosti vsakega vira: pri Ponsu in Termanii denimo nevključenost južnoslovanskih jezikov, pri Franu morebitni zavajajoči podatki iz manj relevantnih virov, npr. narečnih ali zgodovinskih slovarjev, pri jezikovnih virih, ki temeljijo na avtomatskem luščenju podatkov, nezanesljivost informacij ipd.

\subsection{Interaktivne naloge}

Da bi bil ogled posnetkov za študente bolj dinamičen in osmišljen, je v vsak posnetek vključenih nekaj interaktivnih nalog. Seveda v njih ne gre za preverjanje tega, ali študenti razumejo besedišče, ki se pojavlja v korpusnih, slovarskih in drugih primerih v posnetkih. Naloge preverjajo izključno to, kako dobro razumejo predstavljeno snov oz. ali se znajdejo pri iskanju po predstavljenih virih. Namen naloge na Sliki 1 torej ni, da se študenti naučijo, kateri so najpogostejši samostalniki, ki se začnejo z do-, pač pa, da znajo v korpusu poiskati podatek o njihovi pogostnosti. 


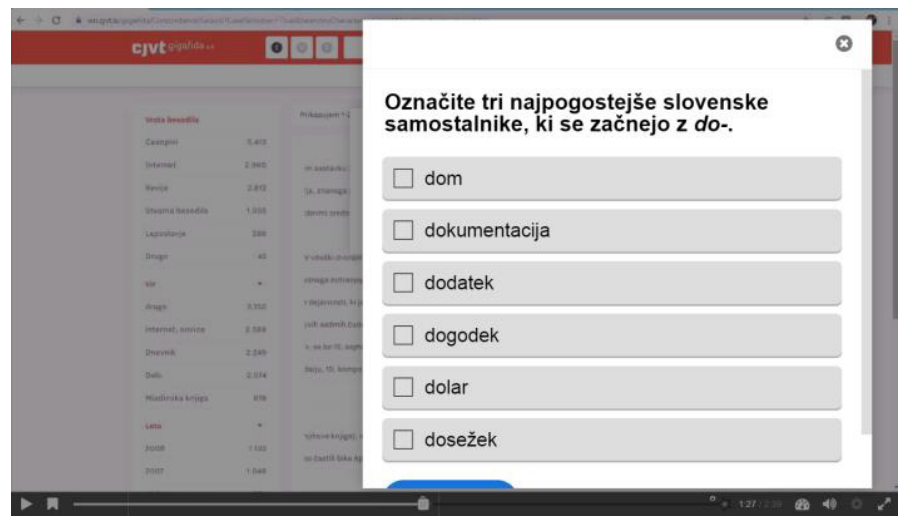

Slika 1: Naloga za iskanje po seznamih v korpusu Gigafida.

Vključene naloge so različnih vrst, kot to omogočata Moodle oz. odprtokodni okvir $\mathrm{H}_{5} \mathrm{P}$. Vse so zaprtega tipa, torej takšne, da se odgovori lahko avtomatsko preverjajo. V nekaterih nalogah morajo študenti vpisovati odgovore; takšne so npr. naloga za iskanje ženskih oblik samostalnikov v Franu (Slika 2), za iskanje ustreznih sklonskih oblik v Sloleksu (Slika 3) ali za iskanje prevodov v različnih slovarskih portalih (Slika 4). Pri slednjem smo za iskanje prevodov v tuje jezike izbrali jezike, ki so južnoslovanskim študentom manj znani, npr. nemščino ali nizozemščino. Tako morajo za iskanje dejansko uporabiti splet.

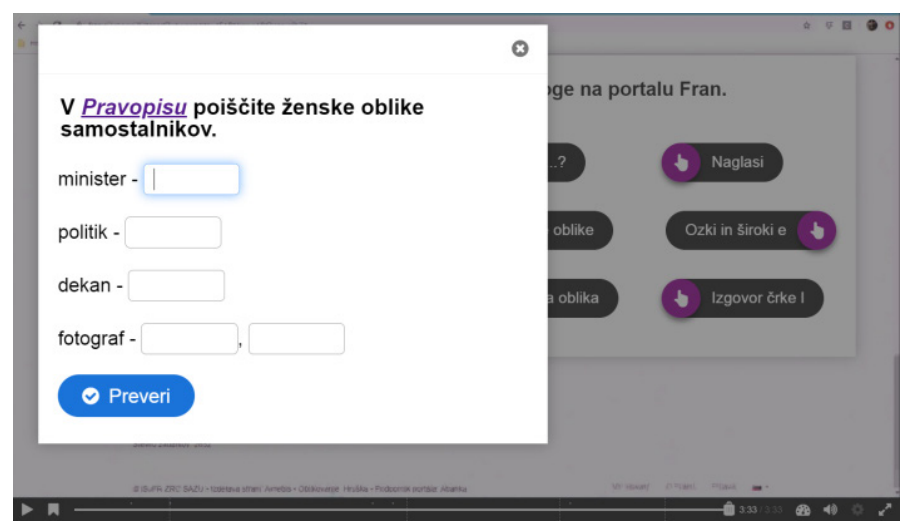

Slika 2: Naloga za iskanje ženskih oblik samostalnikov v Franu. 


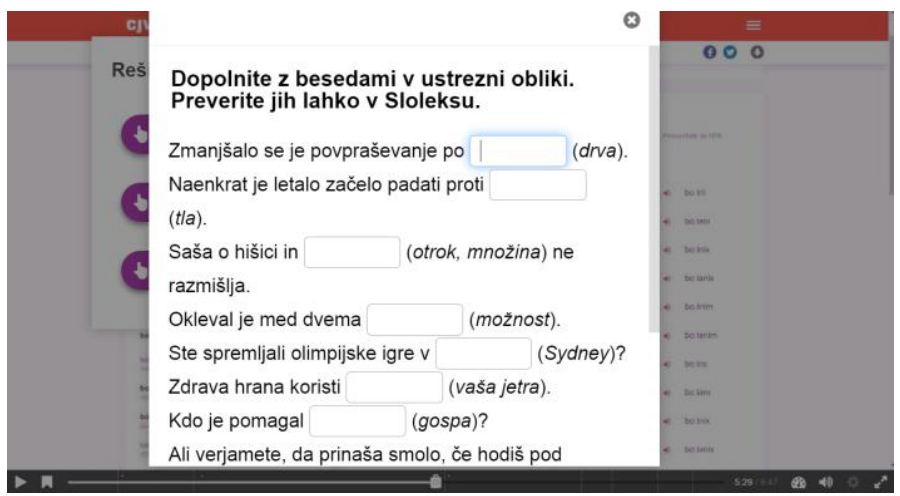

Slika 3: Naloga za uporabo pregibnika Sloleks.

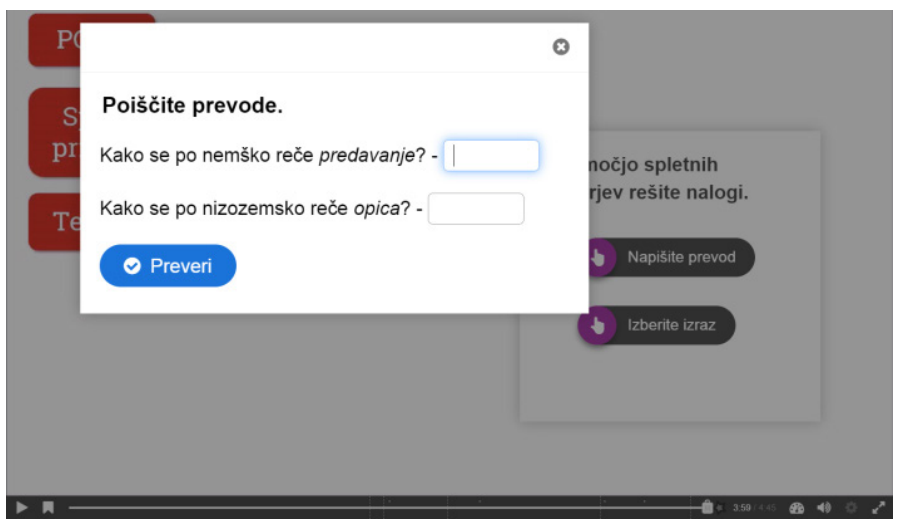

Slika 4: Naloga za iskanje prevodov v tuje jezike.

Večina nalog je izbirnega tipa. Študenti na podlagi podatkov v jezikovnih virih izberejo enega (ali več) od ponujenih odgovorov. Takšna je denimo naloga za osnovno iskanje (Slika 5) v korpusu Gigafida. Prikaz terminoloških slovarjev je popestren z nalogo za iskanje razlag besed oz. sopomenk (Slika 6). Z nalogo izbirnega tipa preverjamo tudi, ali znajo študenti najti informacije o izgovorjavi v Franu (Slika 7). 

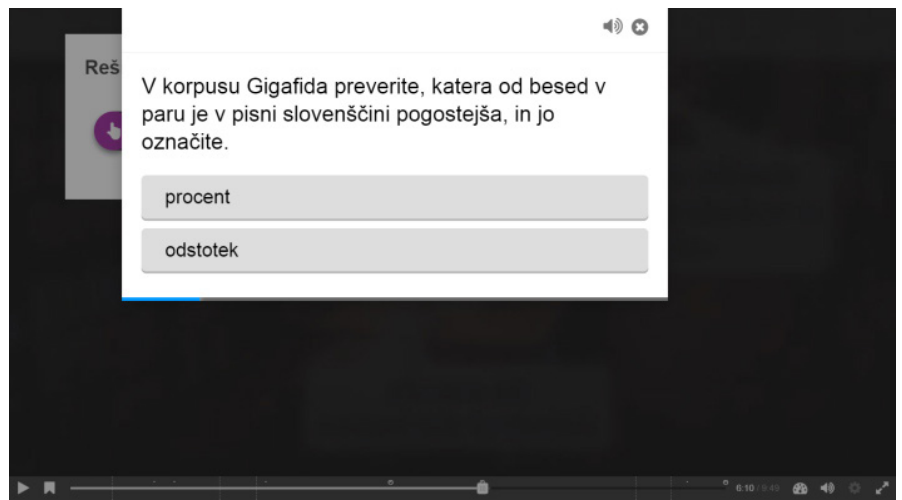

Slika 5: Naloga za osnovno iskanje po korpusu Gigafida.

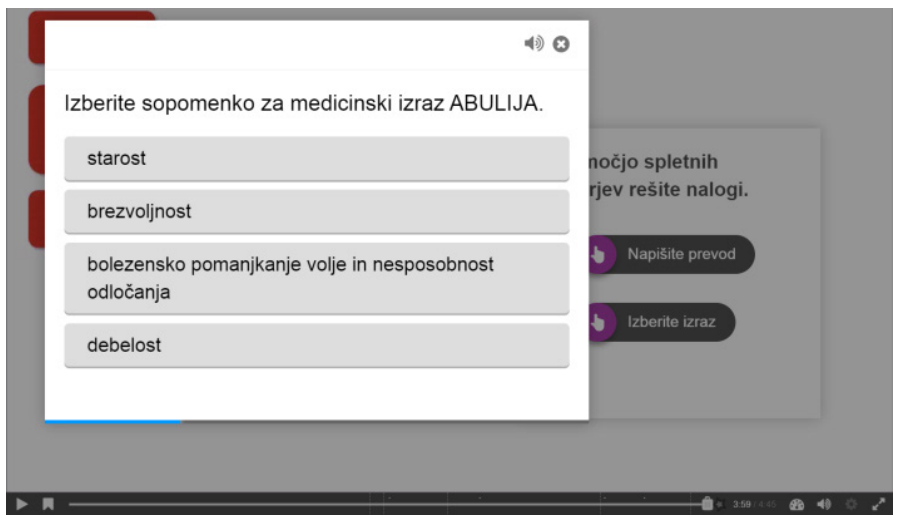

Slika 6: Naloga za izbor sopomenk strokovnega termina.

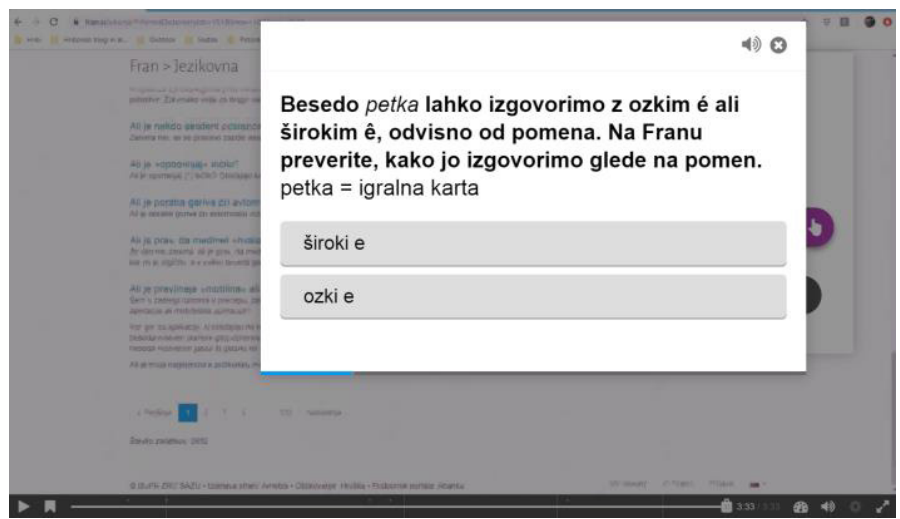

Slika 7: Naloga za iskanje podatkov o širini oz. ožini samoglasnikov v Franu. 
Da je reševanje nalog bolj raznovrstno, je v odgovoru lahko zahtevana tudi številka (Slika 8).

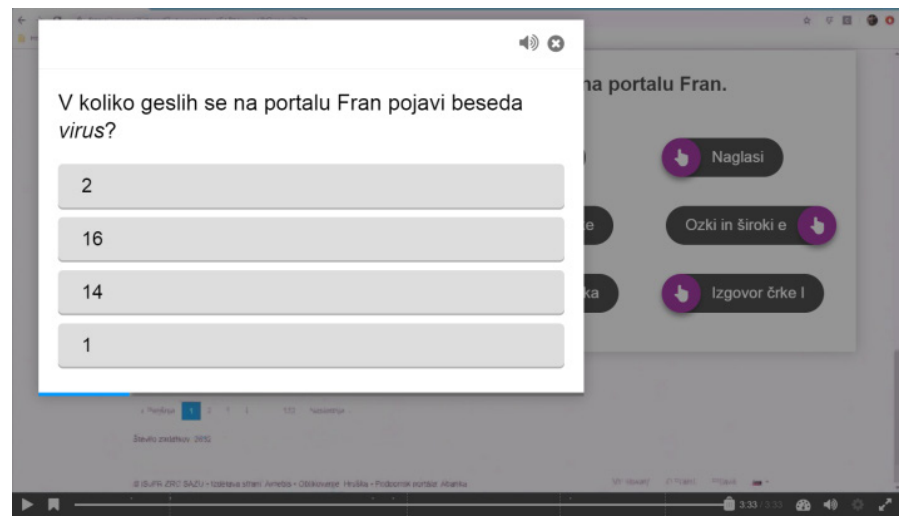

Slika 8: Naloga za določanje števila gesel v Franu.

V naloge so vključeni primeri, ki so za našo ciljno populacijo zahtevni (npr. v nalogo za iskanje po seznamu je vključen samostalnik večer, katerega oblike so zaradi nepodaljševanja osnove $\mathrm{v}$ odvisnih sklonih $\mathrm{z}-j$ - in podobnosti z besedo večerja za južnoslovanske govorce zahtevne, Slika 9), zanimivi ali pa, predvidoma, vsaj zabavni (Slika 10).

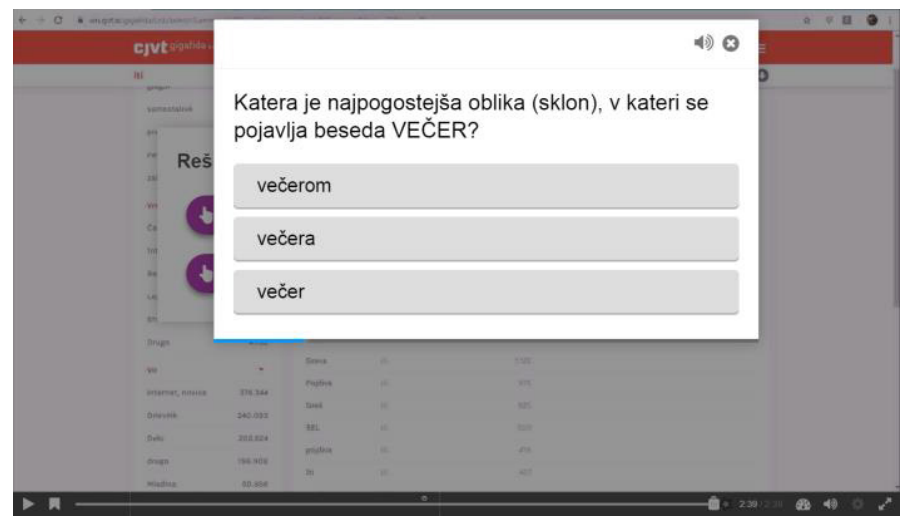

Slika 9: Naloga za iskanje po seznamih. 


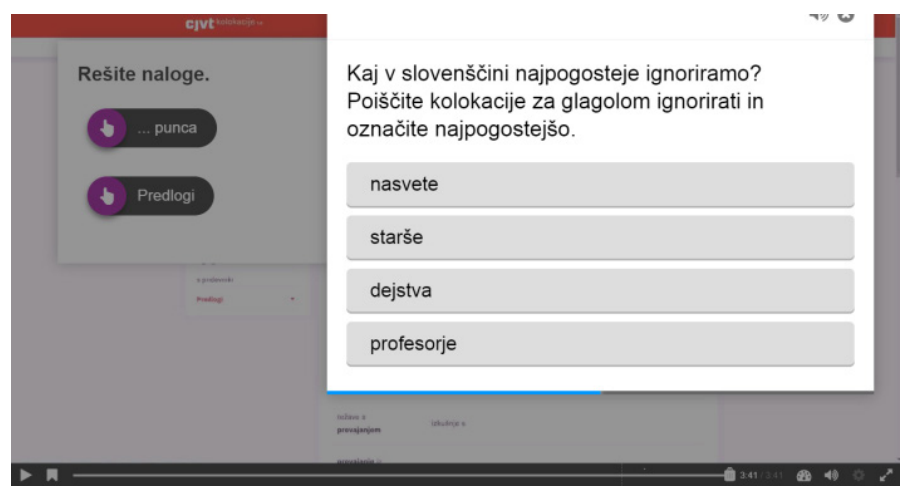

Slika 1o: Naloga za iskanje najpogostejših kolokacij.

\section{MNENJA ŠTUDENTOV}

\subsection{Ocena uporabnosti delavnice o jezikovnih virih in tehnologijah}

Učitelji Leta plus od študentov ves čas dobivamo povratne informacije o njihovem učenju slovenščine. To vključuje tudi uporabo jezikovnih virov in tehnologij. Zapisov pogovorov s študenti, ki so delavnico rabe spletnih orodij na lektoratu ali izpitu večkrat izpostavili kot posebej koristno, zaradi anekdotičnosti nima smisla navajati. Omenim pa naj pisni izpit ob koncu letnega semestra, v katerem morajo študenti v slovenščini napisati daljše besedilo in komentirati preteklo leto, izobraževanje na daljavo, lektorat slovenščine, dodatne dejavnosti pri lektoratu, življenje v Ljubljani in podobno. Ena od v navodilu izpostavljenih točk je bila tudi, naj komentirajo dodatne dejavnosti. Od 34 študentov, ki so ob koncu letnega semestra 2019/20 opravljali pisni izpit, jih je 14 omenilo spletno delavnico jezikovnih virov in tehnologij. En študent je napisal, da tega ne potrebuje, ker »[ima] doma punco katera [mu] pomaga «, ${ }^{5}$ preostalih 13 pa je tečaj pohvalilo kot koristen, npr.: »Od vsih dodatnih dejavnosti največ mi je bil zanimiv ta tečaj spletnih orodij za slovenščino kar sem se veliko naučil in še vedno uporabljam Sloleks ko imam težave z uporabo sklona (kar je nažalost pogosto).« Omenili so, da teh vsebin prej niso poznali: »Navduševljena sem z SOS in mi je žal ker za te korpuse nisem znala prej.« Trije študentje so predlagali, da bi morala biti delavnica spletnih orodij izvedena že v prvem semestru učenja slovenščine: »Priporočil bi da spletna orodja

5 Izjave študentov so navedene v izvirni obliki, z izvirnimi napakami. 
za slovenski jezik (predvsem Sloleks) pokažete študentom v prvem semestru, ker so zelo zelo koristna in veliko pomagaju v učenju.«

Podobne povratne informacije smo dobili tudi v evalvaciji, ki jo ob koncu vsakega od lektoratov na Letu plus izpolnijo študenti. V njej ne sprašujemo eksplicitno po posameznih dodatnih dejavnostih, vendar jih nekateri samoiniciativno komentirajo. Ob koncu letnega semestra 2018/19, ko je delavnica potekala v fizični obliki, je anketo izpolnilo 265 študentov. Med komentarji na koncu so bili trije povezani z delavnico spletnih jezikovnih virov in tehnologij. Dva študenta sta napisala, da bi delavnica morala biti izvedena že $\mathrm{v}$ prvem semestru, en študent pa jo je ocenil negativno kot bistveno predolgo: »da bi imeli 3 ure tečaj za slovenske vire je res zgubljanje časa«. V študijskem letu 2019/20 je bila evalvacija, tako kot vse ostalo, izvedena na spletu. Odgovorov je bilo zato manj, 115. Tudi v tej evalvaciji sta dva študenta pohvalno ocenila delavnico in predlagala, da bi morala biti izvedena že v prvem semestru.

\subsection{Anketa o uporabi jezikovnih virov in tehnologij}

Da bi od študentov o uporabi jezikovnih virov pridobila neposredna mnenja, sem oblikovala še spletno anketo, ki je bila odprta od konca julija do konca septembra 2020. K reševanju so bili prek elektronske pošte pozvani vsi študenti Leta plus, ki so zaključili z lektoratom Slovenščina 2 v študijskih letih 2018/19 (okoli 250 študentov) in 2019/20 (okoli 190 študentov). Anketo je rešilo 99 študentov, 43 \% iz študijskega leta 2018/19 in 57 \% iz 2019/20. Glede na to, da so bili k izpolnjevanju povabljeni sredi poletja, ko je precejšen del študentov odmaknjen od študijskih obveznosti, in da je bil posebej za študente iz leta 2018/19 lektorat slovenščine časovno že oddaljen, sem bila z odzivom zadovoljna.

V skladu z zgornjima deležema je primerljiva delitev študentov glede na način opravljanja delavnice za uporabo jezikovnih virov: 43 se jih je delavnice udeležilo fizično v računalniški učilnici, 53 pa v spletni učilnici. ${ }^{6}$ Obe skupini študentov, t. i. fizično in spletno, bom tudi primerjala, čeprav je treba upoštevati, da so določene razlike med njima nedvomno posledica sprememba medija poučevanja, druge razlike pa so lahko posledica drugih dejavnikov, zato na osnovi te ankete ni mogoče enoznačno sklepati o izvoru teh razlik.

6 Trije študenti so izbrali odgovor »drugo«, vendar v komentarju niso razumljivo pojasnili svojega odgovora. 
Vsi anketiranci so kot prvi jezik govorili enega od južnoslovanskih jezikov: makedonščino (32 \%), srbščino (28 \%), bosanščino (19 \%), črnogorščino (2 \%), hrvaščino (1 \%), ruščino (1 \%). Izjema so trije študenti s prvim jezikom albanščino, madžarščino oz. turščino. Med odgovarjajočimi je bilo 56 žensk in 29 moških. 14 študentov prihaja z Ekonomske fakultete; 9 s Filozofske fakultete; po $5 \mathrm{~s}$ Fakultete za elektrotehniko, Fakultete za gradbeništvo in geodezijo, Fakultete za matematiko in fiziko, Fakultete za računalništvo in informatiko; po 4 s Fakultete za družbene vede in Naravoslovnotehniške fakultete; po 2 z Biotehniške fakultete in Fakultete za strojništvo; po 1 pa z Akademije za likovno umetnost in oblikovanje, Fakultete za arhitekturo, Fakultete za socialno delo, Medicinske fakultete, Pedagoške fakultete in Pravne fakultete. 57 jih študira na prvi stopnji, 28 na drugi, eden pa na doktorski stopnji. Večina študentov, ki so odgovarjali na anketo, študira v slovenščini (76), $10 \mathrm{v}$ angleščini, eden pa »v italijanščini, španščini in slovenščini«.

Ker je dejavnost, pri kateri so jezikovni viri in tehnologije najlažje uporabni, pisanje, je zanimiv podatek, da anketirani študenti v slovenščini dejansko precej pogosto pišejo ${ }^{7}$ (Grafikon 2) - največ pri spletnem sporazumevanju s pedagoškim osebjem - in da je torej uporaba jezikovnih virov zanje še kako relevantna. Med drugimi priložnostmi, ko uporabljajo pisno slovenščino, so

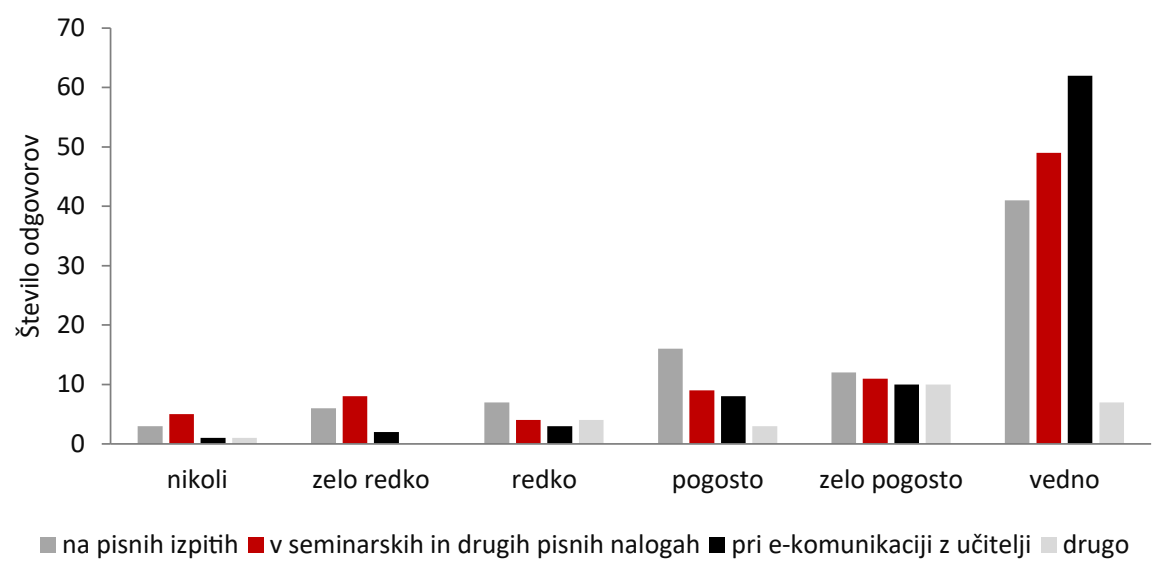

Grafikon 2: Pogostnost pisanja v slovenščini.

7 Anketa sicer ne daje odgovora na to, koliko je dejanske pisne produkcije študentov, temveč samo, kako pogosto pri tem - po lastni samooceni - uporabljajo slovenščino. 
navedli vsakdanje življenje (3 odgovori), pogovor s slovenskimi kolegi oz. prijatelji (3 odgovori) in iskanje študentskega dela (1 odgovor).

\subsubsection{Pogostnost uporabe jezikovnih virov pri študiju}

Študenti so morali za vsakega od naštetih jezikovnih virov, ki so bili vsi predstavljeni v delavnici spletnih orodij za slovenščino, oceniti, kako pogosto jih uporabljajo pri študiju. Izbrali so eno od šestih ocen: nikoli, redkeje, enkrat na mesec, nekajkrat na mesec, enkrat na teden, večkrat na teden. Preračunana povprečja, prikazana na Grafikonu 3 in v Tabeli 2, nam dajo primerjavo, katere vire študenti uporabljajo pogosteje.

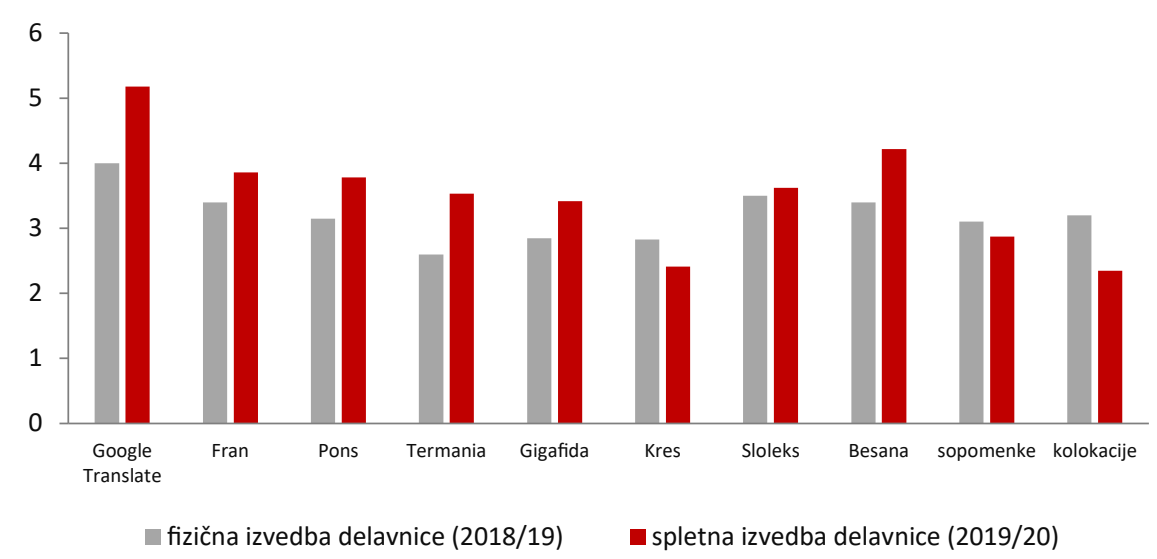

Grafikon 3: Povprečne ocene pogostnosti uporabe jezikovnih virov.

Pri skoraj vseh virih so ocene višje pri študentih spletne skupine. Verjetno na to vpliva spletni način študija, zaradi katerega študenti preživijo na spletu bistveno več študijskega časa, kot kadar se pedagoškega procesa udeležujejo fizično v predavalnicah, zato so jim spletni viri večino časa na dosegu miške. Po pričakovanjih študenti obeh skupin najpogosteje uporabljajo Googlov Prevajalnik oz. Google Translate. Pri tem izstopajo študenti spletne skupine. Sledijo Sloleks, pregibnik Amebis Besana, Fran in Pons. Ostale vire uporabljajo redkeje. 
Tabela 2: Preračunane povprečne ocene pogostnosti rabe posameznih jezikovnih virov in tehnologij, vključenih $v$ delavnico spletnih orodij za slovenščino

\begin{tabular}{l|r|r}
\hline \multirow{2}{*}{$\begin{array}{l}\text { Jezikovni vir oz. } \\
\text { tehnologija }\end{array}$} & $\begin{array}{r}\mid c \\
\text { Povprečna ocena }\end{array}$ \\
\cline { 2 - 3 } Google Translate & 4,02 & $\begin{array}{r}\text { Spletna izvedba delavnice } \\
\mathbf{( 2 0 1 9 / 2 0 )}\end{array}$ \\
\hline Fran & 3,46 & 5,18 \\
\hline Pons & 3,15 & 3,86 \\
\hline Termania & 2,57 & 3,78 \\
\hline Gigafida 2.0 & 2,85 & 3,53 \\
\hline Kres & 2,83 & 3,42 \\
\hline Sloleks 2.0 & 3,5 & 2,41 \\
\hline Pregibnik Amebis Besana & 3,4 & 3,62 \\
\hline Sopomenke 1.0 & 3,06 & 4,23 \\
\hline Kolokacije 1.0 & 3,23 & 2,87 \\
\hline
\end{tabular}

Oglejmo si še odgovore za najpogosteje uporabljane jezikovne vire. Pri strojnem prevajalniku Google Translate (Grafikon 4) je izrazita razlika med študenti fizične in spletne skupine. Po pričakovanjih največji del študentov spletne skupine prevajalnik uporablja večkrat na teden, večina odgovorov pa je zgoščena na pogostejši strani kontinuuma. Pri študentih fizične skupine so odgovori bolj razpršeni.

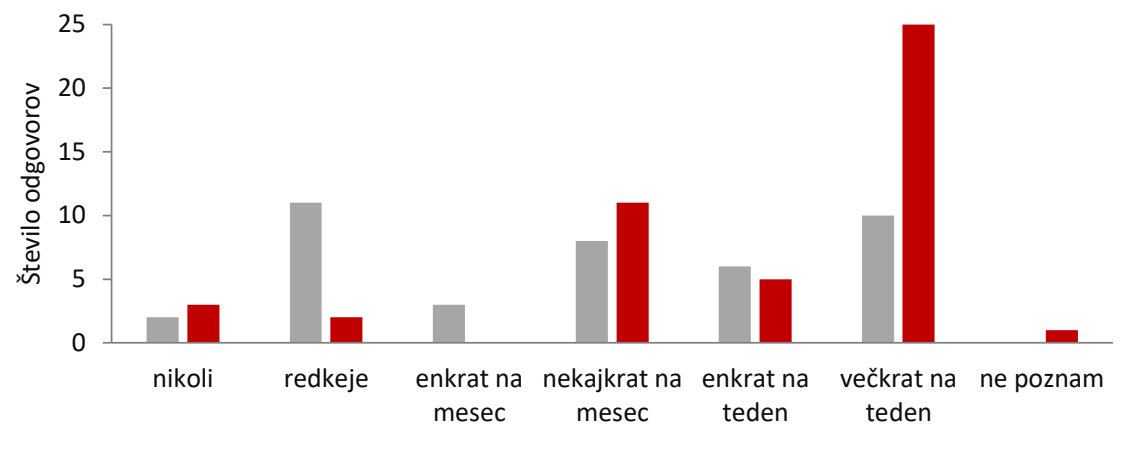

fizična izvedba delavnice (2018/19) —spletna izvedba delavnice (2019/20)

Grafikon 4: Pogostnost uporabe prevajalnika Google Translate. 
Med tremi slovarskimi portali tuji študenti najpogosteje uporabljajo Fran (Grafikon 5), sledi mu Pons (Grafikon 6). Termanio, pri kateri je največ študentov izbralo odgovor »nikoli«, uporabljajo najredkeje (Grafikon 7). Vse tri portale študenti spletne skupine uporabljajo večkrat kot študenti fizične skupine.

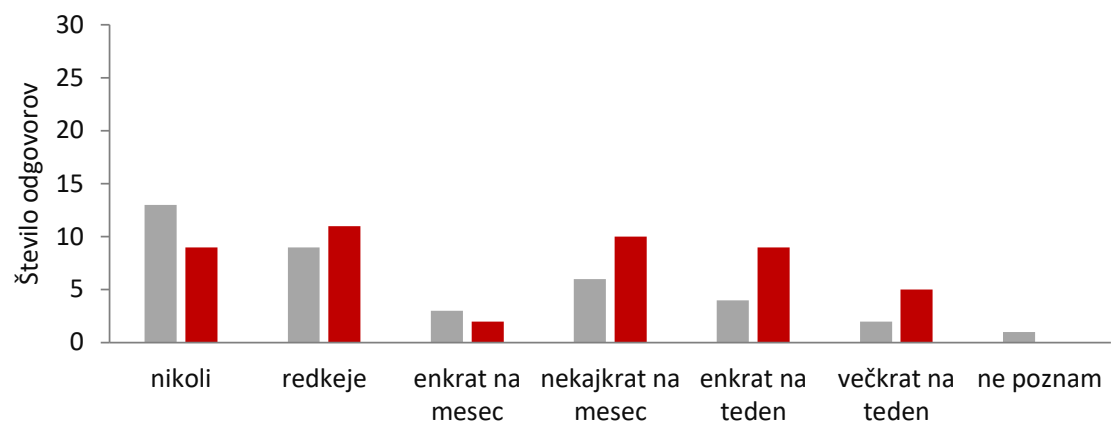

- fizična izvedba delavnice (2018/19) — spletna izvedba delavnice (2019/20)

Grafikon 5: Pogostnost uporabe portala Fran.

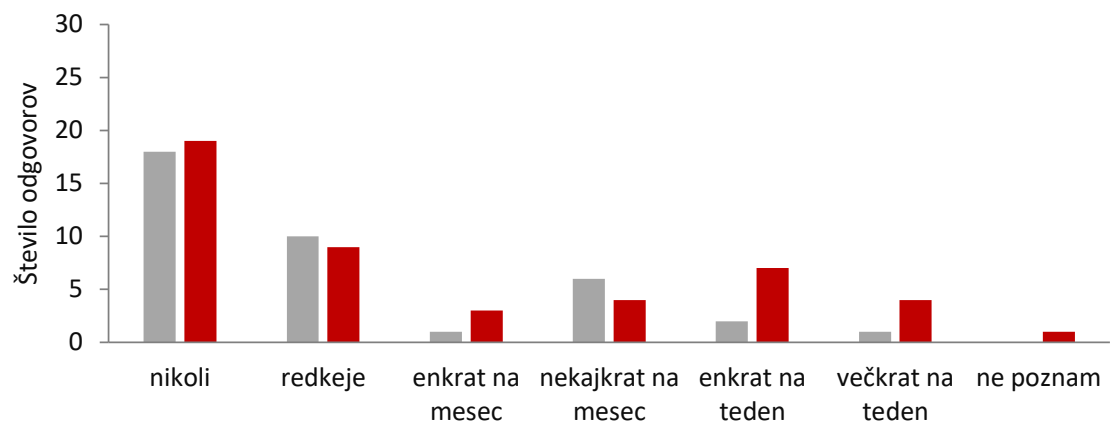

- fizična izvedba delavnice (2018/19) — spletna izvedba delavnice (2019/20)

Grafikon 6: Pogostnost uporabe portala Pons. 


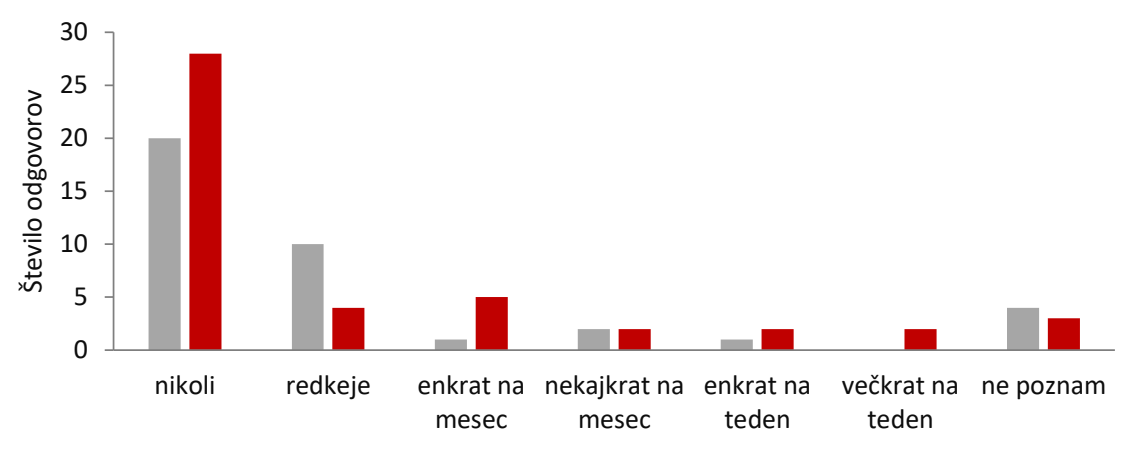

—izična izvedba delavnice (2018/19) — spletna izvedba delavnice (2019/20)

Grafikon 7: Pogostnost uporabe portala Termania.

V anketo sta bila vključena dva jezikovna korpusa, Gigafida in Kres. Kres (Grafikon 8) uporabljajo študenti najredkeje med vsemi obravnavami viri, kar je v skladu s tem, da jim je bil na usposabljanju predstavljen mimogrede kot manjša različica Gigafide. A tudi slednjo (Grafikon 9) uporabljajo razmeroma redko. Kot zanimivost naj omenim, da sta med petimi študenti obeh skupin, ki so izbrali odgovor »večkrat na teden«, le dva s Filozofske fakultete, torej morda jezikoslovca. Dva študenta sta s Fakultete za elektrotehniko, eden pa z Ekonomske fakultete. Odločitev za rabo spletnih jezikovnih virov torej ni odvisna od (jezikoslovne) stroke, pač pa od drugih subjektivnih dejavnikov, kakršni so osebni interesi in nagnjenja.

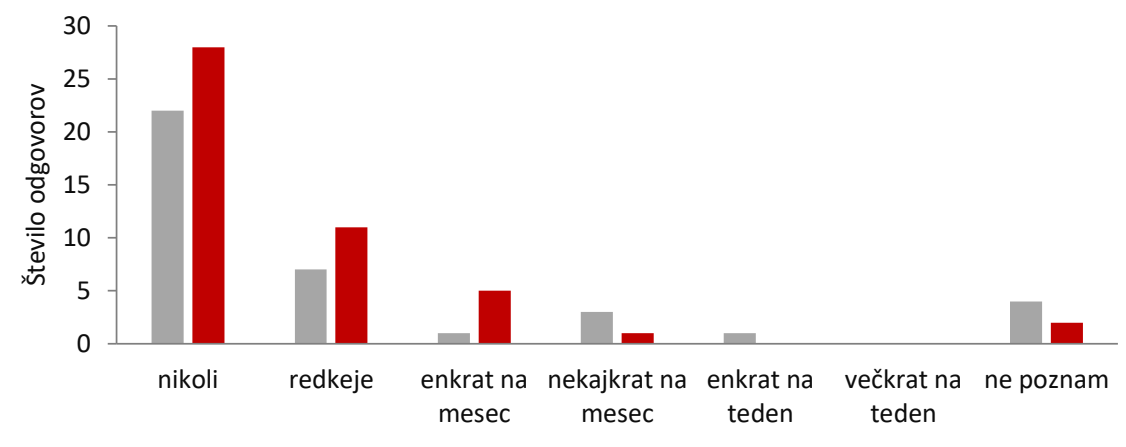

- fizična izvedba delavnice (2018/19) — spletna izvedba delavnice (2019/20)

Grafikon 8: Pogostnost uporabe korpusa Kres. 


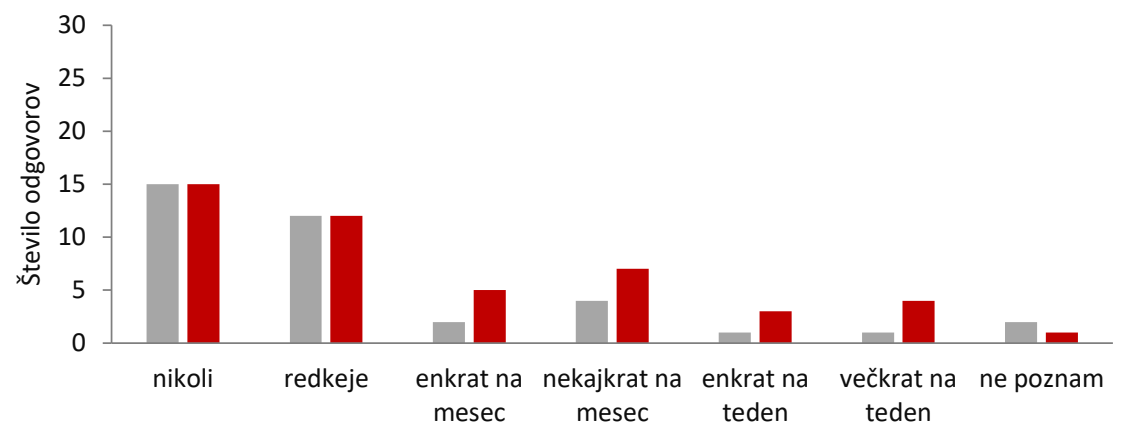

—izična izvedba delavnice (2018/19) — spletna izvedba delavnice (2019/20)

Grafikon 9: Pogostnost uporabe korpusa Gigafida.

Med viri s podatki o pregibanju besed ima Sloleks (Grafikon 10) nekaj prednosti pred pregibnikom Besana (Grafikon 11).

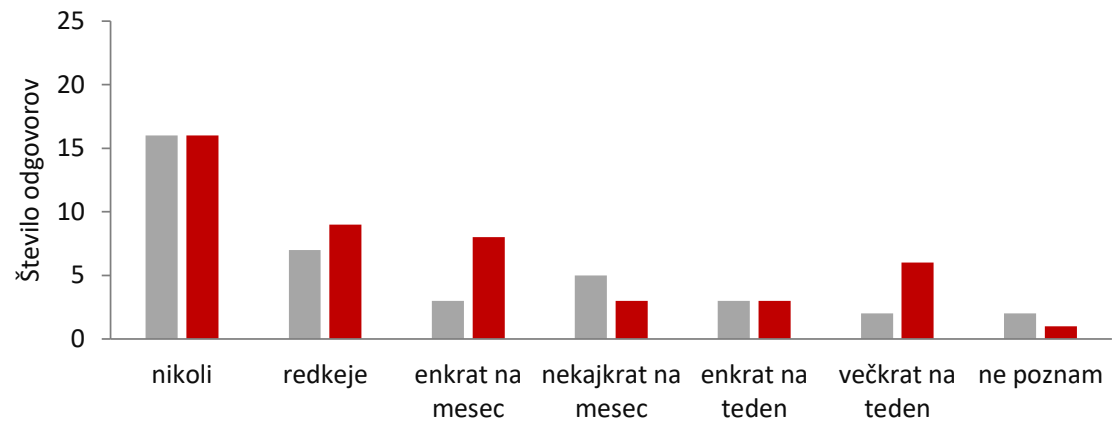

fizična izvedba delavnice (2018/19) — spletna izvedba delavnice (2019/20)

Grafikon 10: Pogostnost uporabe Sloleksa. 


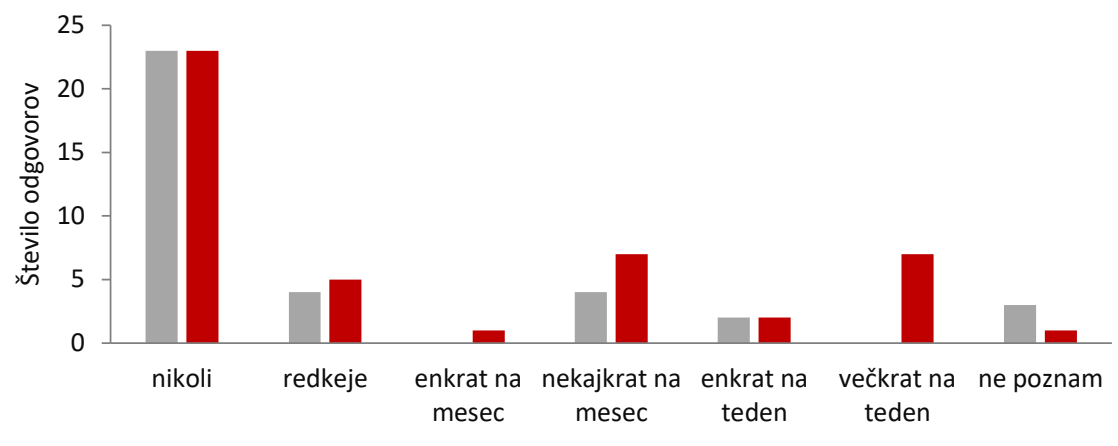

- fizična izvedba delavnice (2018/19) $\quad$ spletna izvedba delavnice (2019/20)

Grafikon 11: Pogostnost uporabe pregibnika Amebis Besana.

Poglejmo si še malo bolj specializirana slovarja, slovar sopomenk Sopomenke 1.o (Grafikon 12) in kolokacij Kolokacije 1.o (Grafikon 13). Oba študenti obeh skupin uporabljajo bolj ali manj samo izjemoma.

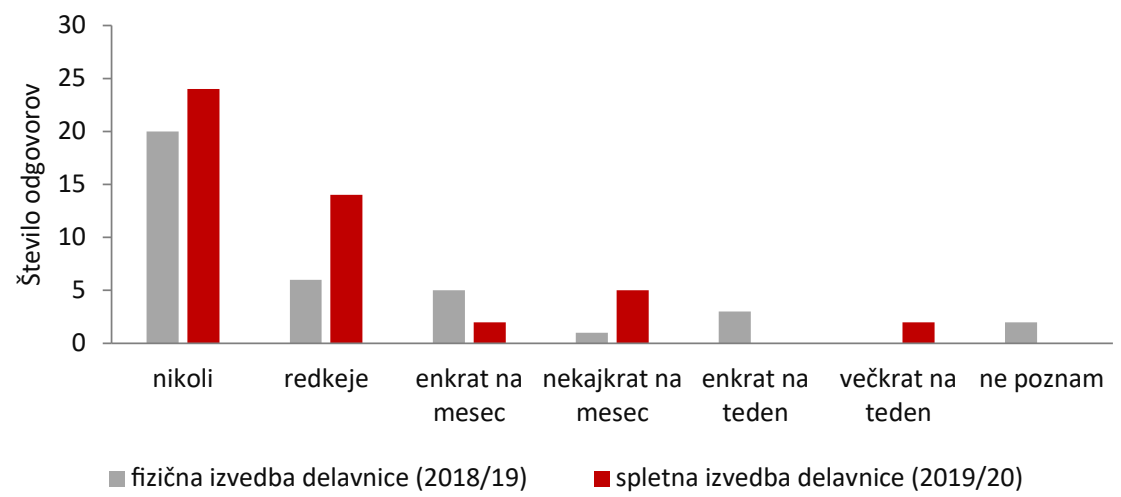

Grafikon 12: Pogostnost uporabe sopomenskega slovarja Sopomenke 1.o. 


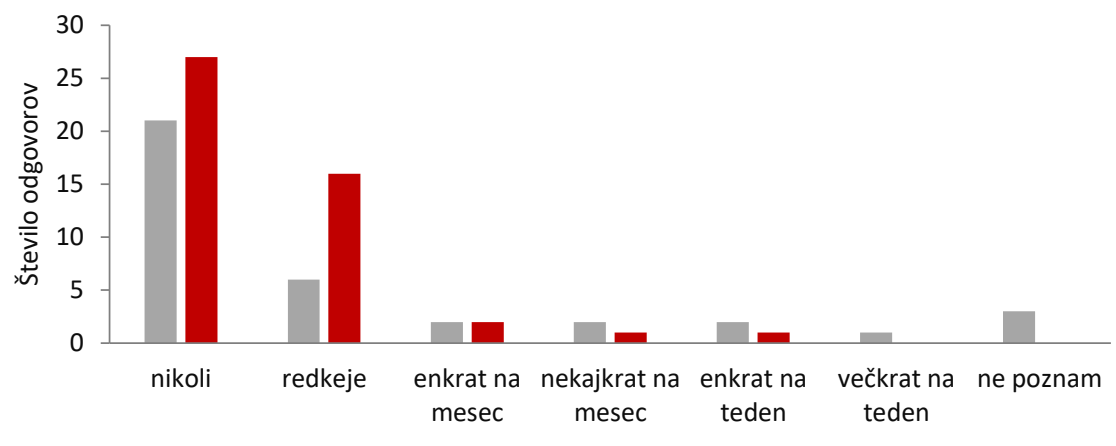

- fizična izvedba delavnice (2018/19) - spletna izvedba delavnice (2019/20)

Grafikon 13: Pogostnost uporabe kolokacijskega slovarja Kolokacije 1.o.

Kot je razvidno iz grafikonov, so pri vsakem viru študenti lahko izbrali tudi odgovor »ne poznam«. Izvajalci lektorata smo zadovoljni, da so bile te številke v anketi razmeroma nizke. Nekoliko višje so pri študentih iz generacije 2018/19, kar je razumljivo, ker je delavnica spletnih virov od njih že bolj odmaknjena.

\subsubsection{Najuporabnejši jezikovni viri}

Študente sem prosila tudi, naj izberejo največ tri jezikovne vire, ki so zanje najuporabnejši (Grafikon 14). Dodatno so v komentarju lahko pojasnili, za kaj jih uporabljajo. Dobila sem 48 komentarjev, v katerih so poleg pojasnil uporabe navajali tudi argumente, zakaj se jim zdijo najuporabnejši.

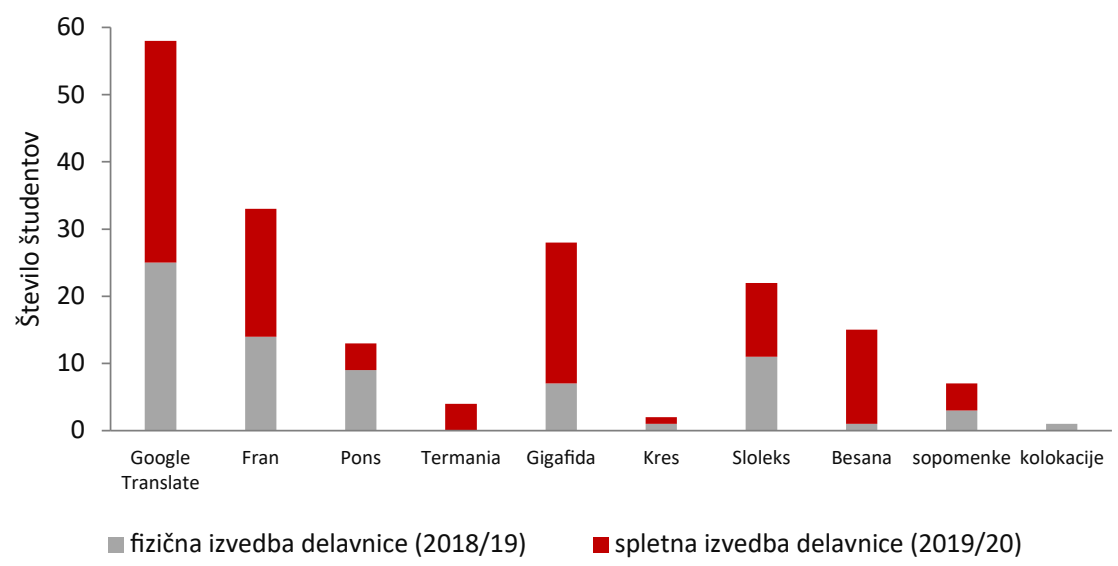

Grafikon 14: Najuporabnejši jezikovni viri po oceni študentov. 
Med splošnimi komentarji je zanimiva opazka študenta, ki spletna orodja uporablja, ker je njegova jezikovna zmožnost v slovenščini prenizka: »Zgoraj označena orodja uporabljam najpogosteje ker v mojemu vokabularju še vedno ni dovolj besed za pisno komunikacijo v slovenščini. Verjamem da bom jih vse uporabljal takrat ko bom moral več uporabljati pisno slovenščino. ${ }^{8}$

Če podrobneje pogledamo najuporabnejša orodja po izboru študentov, je na prvem mestu seveda Googlov Prevajalnik, ki je bil najpogostejša izbira študentov obeh skupin. Uporabljajo ga za prevod besed, ki jih ne razumejo (4 odgovori), za pisanje različnih besedil za fakulteto (4 odgovori), pa tudi v vsakdanjem življenju (2 odgovora). Kot glavna argumenta so navedli hitrost (8 odgovorov) in enostavnost uporabe (8 odgovorov), npr. »Zelo so lahka za uporabo in vedno najdem tisto kar iščem. « Dva študenta sta omenila, da več od tega ne potrebujeta - »ima vse kaj potrebujem «. En študent pa je njegovo uporabnost relativiziral: »Zaradi hitre pristupačnosti, čeprav ni najboljše orodje za učenje slovenščine. « Nezanemarljiva prednost Prevajalnika, ki jo je izrecno navedlo 6 študentov, je dejstvo, da so ga večinoma že navajeni: »Ker sem ga že poznala preden sem začela študirati.«

Prevajalniku sledi slovarski portal Fran, ki so ga približno izenačeno izbirali študenti obeh skupin. Uporabljajo ga za iskanje besed, ki jih ne razumejo (3 odgovori), pri študiju ali v vsakdanjem življenju (2 odgovora), za »preverjanje besed, ki obstajajo tudi v bosanščini, vendar se zdi da imajo drugčen pomen «, in za popravljanje napak (1 odgovor). Tudi pri Franu sta kot glavni prednosti navedeni enostavnost uporabe (3 odgovori) - »lahko pridem do beseda ki jo iscem, ne zgubim dodaten cas dokler najdem na kateri gumb moram pritisniti « - in hitrost dostopa do podatkov (1 odgovor), izpostavili pa so tudi kakovost oz. podrobnost informacij (2 odgovora) in "zelo razumljive razlage pomena besed «. En študent pa je izrecno poudaril tudi, da je »navajan [...] na uporabo google translate in frana od samega začetka študija v sloveniji «.

Približno enako pogosto kot Fran so študenti izbirali korpus Gigafida - študenti spletne skupine so ga izbrali celo večkrat kot Fran. Gigafido uporabljajo »zaradi lažjega in pravilnejšega pisanja v slovenščini« ali z zelo splošno utemeljitvijo, ki pa potrjuje koristnost delavnice spletnih orodij: »gigafida mi se

8 Če ni drugače navedeno, so vsi navedki odgovori iz ankete. Zapisani so v izvirni obliki, z izvirnimi napakami. 
zdi zelo korisnom in je pogosto uporabljam od udeležbe na tečaju spletnih orodji.« Njena uporaba naj bi bila hitra in enostavna (3 odgovori), primerna pri prevajanju (2 odgovora) in za preverjanje pogovornih besed (1 odgovor) ali za izbiro ustreznejše besede, kar je študentka utemeljila s primerom iz spletne delavnice: »Gigafido sem uporabljala, če nisem bila zares, katero besedo bom uporabila, na primer odstotek oz. procent.« Drug študent pa je navedel, da Gigafido uporablja »za vse, kar [mu] pride na misel, čist da [preveri], če nekaj obstaja ali katera oblika je pogostejša «. Tretji študent uporablja Gigafido v sklopu Sloleksa kot pokazatelj, kje lahko uporablja določen sklon. Izpostavili so tudi, da »ima najboljše informacije« in - nekoliko nejasno oz. netočno - da so te informacije »najbolj uradne«.

Gigafidi sledi oblikoslovni leksikon Sloleks, ki so ga približno izenačeno izbirali študenti obeh skupin. V njem preverjajo predvsem sklonske oblike (5 odgovorov), posebej »nekih vsakdanjih nepravilnih besed «. Kot prednost so navedli hitrost in enostavnost uporabe (5 odgovorov), en študent pa je izpostavil, da dajeta Sloleks in Besana v primerjavi z Googlovim Prevajalnikom »veliko bolj konkretne in pravilne informacije .

Pri pregibniku Besana je velika razlika med študenti obeh skupin - medtem ko ga študenti fizične skupine skoraj niso izbirali, so ga študenti spletne skupine izbrali celo večkrat kot prosto dostopni Sloleks. Pri tem žal ni razvidno, katero Besanino storitev dejansko uporabljajo. V spletni delavnici so študenti spoznali samo pregibnik, vendar je glede na odgovor dveh študentov, da Besano uporabljata za preverjanje besedila - »Lahko vidim napake, ki sem naredila.« -, mogoče sklepati, da poznajo tudi Besanino avtomatsko lektorico. Besano sicer uporabljajo pri pisanju (2 odgovora) in vsakdanjem govoru (1 odgovor), za preverjanje pregibanja besed (2 odgovora) in za prevajanje (1 odgovor). Po enkrat sta bili izpostavljeni tudi enostavnost uporabe in kakovost informacij.

Ostale jezikovne vire so študenti kot najuporabnejše izbirali precej redkeje. Nekoliko izstopa spletni slovar Pons, ki so ga večkrat izbrali študenti fizične skupine. Uporabljajo ga za prevajanje (2 odgovora), ker je »najlažje in najučinkovitejše«, en študent pa je prostodušno pojasnil, da je na študiju prevajalstva in rabi »vsa mogoča orodja za pomoč«. Med preostalimi viri je bila podana utemeljitev za slovarski portal Termania, ki da se uporablja »za prevajanje 
nekaterih ekonomskih besed «, slovar sopomenk je eden od študentov izbral »kot prevajalec«, drugi pa je utemeljil: »slovar sopomenk pa mi omogoča da se izogibam ponovitvam in obogatim svoje besedišče.«

\section{SKLEP}

Učitelji slovenščine na Letu plus smo prepričani, da so delavnice spletnih orodij za slovenščino za tuje študente na Univerzi v Ljubljani koristne. K sreči to potrjujejo tudi povratne informacije, ki jih dobivamo od študentov. Seveda je treba upoštevati, da so v tem prispevku predstavljeno anketo verjetno reševali samo bolj motivirani študenti; gotovo je med tistimi, ki ankete niso rešili, več takšnih, ki smisla v seznanjanju z jezikovnimi viri in tehnologijami ne vidijo. Ne glede na to se bomo tudi v prihodnosti osredotočali na jezikoslovno bolj motivirane študente in jih v obliki, kakršno nam bodo dopuščale zunajjezikovne okoliščine poučevanja, še naprej usposabljali za uporabo najaktualnejših jezikovnih virov in tehnologij.

Glede na nekatere netočne informacije, ki so jih v anketi navajali študenti (npr. o tem, da so podatki v korpusu Gigafida in Sloleksu najbolj uradni), bomo v prihodnje še bolj opozarjali na to, na čem temeljijo posamezni jezikovni viri, in študente še bolj ozaveščali, da je podatke iz vseh virov in tehnologij treba uporabljati kritično. Vprašanje za prihodnost, ki terja nekaj premisleka, pa je, kdaj jim je smiselno predstavljati te vire in tehnologije. Kot je bilo razvidno iz prispevka, je bila glavnina rahlo negativnih komentarjev študentov, povezanih s temi vsebinami, dejansko povezana s predlogi, da bi to snov spoznali že v prvem semestru svojega študija na Univerzi v Ljubljani. Zaenkrat se za to (še) nismo odločili. Jezikovna zmožnost večine študentov je v prvem semestru namreč nizka, tako da bi lahko imeli težave pri razumevanju metajezika videoposnetkov. Predlog študentov pa nam vendarle služi kot opomnik, da jezikovnotehnološke vsebine še bolj vključujemo v poučevanje že med lektoratom. $Z$ besedami enega od študentov: »[...] če imate vizijo da te vire uporabljamo pogostejše, bi bilo boljše učitelji leta plus na predavanjah uporabljajo z nami.« 


\section{LITERATURA}

\section{Digitalni slovarski in korpusni viri}

Besana: Spletna verzija pregibnika Amebis Besana 4.24.1. Pridobljeno s https://besana.amebis.si/pregibanje/ (2. 9. 2021)

Evrokorpus. Pridobljeno s https://evroterm.vlada.si/evrokorpus (2. 9. 2021)

Fran. Pridobljeno s https://fran.si/ (2. 9. 2021)

Gigafida 2.o: Korpus pisne standardne slovenščine. Pridobljeno s https://viri. cjvt.si/gigafida/ (2. 9. 2021)

Google Prevajalnik. Pridobljeno s https://translate.google.com/ (2. 9. 2021)

GOS. Pridobljeno s http://www.korpus-gos.net/ (2. 9. 2021)

Igra besed. Pridobljeno s https://www.igra-besed.si/ (2. 9. 2021)

Kolokacïje 1.o: Kolokacijski slovar sodobne slovenščine. Pridobljeno s https:// viri.cjvt.si/kolokacije/slv/ (2. 9. 2021)

Kres. Pridobljeno s http://www.korpus-kres.net/ (2. 9. 2021)

Leto plus. Pridobljeno s https://www.uni-lj.si/studij/leto-plus/ (24. 11. 2021)

Pedagoški slovnični portal. Pridobljeno s http://slovnica.slovenscina.eu/ (2. 9. 2021)

PONS spletni slovar. Pridobljeno s https://sl.pons.com/prevod (18. 8. 2021)

Portal jezikovnih virov. Pridobljenos https://viri.trojina.si/ (10. 12. 2021)

Sloleks 2.o: Slovenski oblikoslovni leksikon. Pridobljeno s https://viri.cjvt.si/sloleks/slv/ (2. 9. 2021)

Slovarji: Spletni slovarji in prevajalski pripomočki. Pridobljeno s https://evroterm.vlada.si/slovarji (18. 8. 2021)

Sopomenke 1.o: Slovar sopomenk sodobne slovenščine. Pridobljeno s https:// viri.cjvt.si/sopomenke/ (2. 9. 2021)

Spletni slovar slovenskega jezika. Pridobljeno s http://ssj.slovenscina.eu/spletni-slovar (2. 9. 2021).

Šolar. Pridobljeno s http://korpus-solar.net/ (2. 9. 2021)

Termania. Pridobljeno s https://www.termania.net/ (18. 8. 2021) 


\section{Drugo}

Arhar Holdt, Š., Čibej, J., Dobrovoljc, K., Gantar, A., Gorjanc, V., Klemenc, B., Kosem, I., Krek, S., Laskowski, C., \& Robnik Šikonja, M. (2018). Thesaurus of Modern Slovene: By the Community for the Community. Proceedings of the XVIII EURALEX International Congress: Lexicography in Global Contexts (str. 401-410). Ljubljana: Znanstvena založba Filozofske fakultete. Pridobljeno s https://e-knjige.ff.unilj.si/znanstvena-zalozba/catalog/view/118/211/3000-1 (10. 12. 2021)

Arhar Holdt, Š., Logar, N., Pori, E., \& Kosem, I. (2020). »Game of Words«: play the game, clean the database. Lexicography for inclusion: EURALEX XIX: Congress of the European Association for Lexicography (str. 41-49).

Arhar Holdt, Š., Kosem, I., \& Pori, E. (2021). Jezikovni viri CJVT in njihova raba v izobraževalne namene. Slovenščina na dlani 4 (str. 19-36). Maribor: Univerza v Mariboru, Univerzitetna založba.

Dobrovoljc, K., Krek, S., \& Erjavec, T. (2015). Leksikon besednih oblik Sloleks in smernice njegovega razvoja. V V. Gorjanc, P. Gantar, I. Kosem \& S. Krek (ur.), Slovar sodobne slovenščine: problemi in rešitve (str. 80-105). Ljubljana: Znanstvena založba Filozofske fakultete.

Gantar, P. (2011). Leksikalna baza za slovenščino: komu, zakaj in kako (naprej)? Jezikoslouni zapiski, 17(2), 77-92.

Kosem, I., Stritar, M., Može, S., Zwitter Vitez, A., Arhar Holdt, Š., \& Rozman, T. (2012). Analiza jezikounih težav učencev: Korpusni pristop. Ljubljana: Trojina, zavod za uporabno slovenistiko.

Kosem, I., Krek, S., Gantar, P., Arhar Holdt, Š., Čibej, J., \& Laskowski, C. (2018). Kolokacijski slovar sodobne slovenščine. Zbornik konference Jezikovne tehnologije in digitalna humanistika / Proceedings of the conference on Language Technologies \& Digital Humanities, 20.-21. september 2018, Ljubljana (str. 133-139). Ljubljana: Znanstvena založba Filozofske fakultete v Ljubljani. Pridobljeno s http://www.sdjt.si/wp/wp-content/ uploads/2018/09/JTDH-2018_Kosem-et-al_Kolokacijski-slovar-sodobne-slovenscine.pdf (10. 12. 2021)

Krek, S., Laskowski, C. A., Robnik Šikonja, M., Kosem, I., Arhar Holdt, Š., Gantar, P., Čibej, J., Gorjanc, V., Klemenc, B., \& Dobrovoljc, K. (2018). 
Thesaurus of modern Slovene 1.o. Ljubljana: Slovenian Language Resource Repository CLARIN.SI. Pridobljeno s http://hdl.handle.net/11356/1166 (10. 12. 2021)

Krek, S., Arhar Holdt, Š., Erjavec, T., Čibej, J., Repar, A., Gantar, P., Ljubešić, N., Kosem, I., \& Dobrovoljc, K. (2020). Gigafida 2.0: the reference corpus of written standard Slovene. LREC 2020: Twelfth International Conference on Language Resources and Evaluation: May 11-16, 2020, Marseille, France (str. 3340-3345). Pariz: ELRA - European Language Resources Association. Pridobljeno s http://www.lrec-conf.org/proceedings/lrec2020/ LREC-2020.pdf (10. 12. 2021)

Logar Berginc, N., Grčar, M., Brakus, M., Erjavec, T., Arhar Holdt, Š., \& Krek, S. (2012). Korpusi slovenskega jezika Gigafida, KRES, ccGigafida in ccKRES: gradnja, vsebina, uporaba. Ljubljana: Trojina, zavod za uporabno slovenistiko; Fakulteta za družbene vede.

Stritar Kučuk, M., \& Dobrovoljc, K. (2013). Korpusi na poti v šole. Slovenščina 2.o, 1(1), 181-194.

Verdonik, D., \& Zwitter Vitez, A. (2011). Slovenski govorni korpus Gos. Ljubljana: Trojina, zavod za uporabno slovenistiko.

Željko, M. (2003). Evroterm in Evrokorpus - terminološka baza in korpus prevodov. Mostovi, 37(1), 62-72. 


\section{ON-LINE SLOVENE LANGUAGE RESOURCES AND FOREIGN STUDENTS AT THE UNIVERSITY OF LJUBLJANA}

In the first year of their studies at the University of Ljubljana, regularly enrolled foreign students are entitled to Slovene language classes within the Year Plus module. In the second semester of language classes, they learn about online Slovene language resources and technologies in a special workshop. This paper describes this workshop in the academic year 2019/20, when it was organized virtually due to the coronavirus pandemic, in the form of interactive videos with tasks to check students' understanding of the material. The second part of the paper focuses on students' perceptions of such language resources and technologies. With an online survey I analysed the views and experiences of two generations of students: students of the 2018/19 generation participated in this workshop in the classroom, while students of the 2019/20 generation participated on-line. According to the survey results, the younger generation of students uses online language resources more frequently. Students in both groups use Google Translate most often, followed by Sloleks, Besana, Fran and Pons. Their main arguments for using these resources are that they are fast and easy to use, or that students are the most accustomed to a particular resource.

Keywords: on-line language resources, Slovene language, foreign students, on-line learning

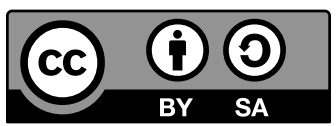

To delo je ponujeno pod licenco Creative Commons: Priznanje avtorstva-Deljenje pod enakimi pogoji 4.o Mednarodna. / This work is licensed under the Creative Commons Attribution-ShareAlike 4.o International. 